\title{
Scientometric profile of physiotherapists Brazilian scientists
}

\author{
Perfil cientométrico dos fisioterapeutas cientistas brasileiros
}

\author{
Flávia Galvão Cruz ${ }^{[a]}$, Tainara Adriele Neves Cedro ${ }^{[a]}$, Samuel Barbosa Camargo ${ }^{[b]}$, Kátia Nunes Sá ${ }^{[a,]^{*}}$ \\ [a] Universidade Católica de Salvador (UCSal), Salvador, BA, Brazil \\ [b] Fundação Oswaldo Cruz (FIOCRUZ), Salvador, BA, Brazil \\ [c] Escola Bahiana de Medicina e Saúde Pública (EBMSP), Salvador, BA, Brazil
}

\begin{abstract}
Introduction: Knowledge of Brazilian scientists profile is important to understand the factors that influence the behavior of those interested in developing science. Objective: To outline the profile of Brazilian physiotherapist researchers, permanent, or collaborator professors of PhD programs in physiotherapy. Methods: Study of documentary analysis with scientometric techniques on physiotherapist data in Brazilian doctors associated professors in PhD programs. To identify the professors, the Sucupira and Lattes Platforms were used, and the research areas were categorized according to COFFITO. Data on the research area, the number of orientations, publications and impact factor average (JCR) were analyzed by 1-way ANOVA test ( $<<0.05$ ), and a collaboration network was built using Gephi 0.9.1 software. Results: Nine institutions of higher education in Brazil have a PhD in physiotherapy. A total of 119 professors are associated with UFMG (20.2\%), UFSCAR (17.6\%), UFRN (13.4\%), and UNINOVE (10.9\%). The median number of doctors graduated by the professors was $1.0(0.0-6.0)$ and in publications in the period was 4.6 (2.4 - 8.4). The main study designs were observational 71 (59.7\%), and the main research area was neurofunctional 25 (21.0\%). The collaboration between UFSCAR and UFMG professors is strengthened. Conclusion: There are few specific doctoral programs for physiotherapists in Brazil. The majority of them are concentrated in the southeast region, and the professor staff have very heterogeneous characteristics related to the duration of the programs, the nature of the institution, or the affiliation of the professor.
\end{abstract}

Keywords: Scientometrics. Physical Therapy Specialty. Research.

\footnotetext{
* FGC: BS, e-mail: flaviagalvao.c@gmail.com

TANC: BS, e-mail: adrieletay@gmail.com

SBC: PhD, e-mail: camargo.fisio2016@gmail.com

KNS: PhD, e-mail: katia.sa@gmail.com
} 


\section{Resumo}

Introdução: Conhecer o perfil dos cientistas brasileiros é importante para compreender fatores que influenciam os comportamentos dos interessados em desenvolver ciência. Objetivo: Delinear o perfil dos Fisioterapeutas doutores pesquisadores brasileiros, docentes permanentes ou colaboradores dos programas de doutorado em Fisioterapia. Métodos: Estudo de análise documental com técnicas de Cientometria sobre dados de fisioterapeutas doutores brasileiros docentes de programas de doutorado. Para identificar os profissionais, foram utilizadas as Plataformas Sucupira e Lattes e as áreas de pesquisa foram categorizadas de acordo com o COFFITO. Dados sobre área de pesquisa, número de orientações, publicações e média do fator de impacto (JCR) foram analisados pelo teste ANOVA Oneway $(p<0,05)$ e uma rede de colaboração foi construída com auxílio do software Gephi 0.9.1. Resultados: Nove instituições de ensino superior no Brasil possuem doutorado específico em Fisioterapia. Um total de 119 doutores estão vinculados majoritariamente à UFMG (20,2\%), UFSCAR (17,6\%), UFRN (13,4\%) e UNINOVE (10,9\%). A mediana de doutores formados pelos docentes foi de 1,0 $(0,0-6,0)$ e de publicações foi de publicações no período foi de 4,6 (2,4;8,4). Os principais desenhos de estudo foram observacionais 71 (59,7\%) e a principal área de pesquisa foi a neurofuncional 25 (21,0\%). A colaboração entre os docentes da UFSCAR e UFMG é consolidada. Conclusão: Existem poucos programas de doutoramento específico para Fisioterapeutas no Brasil. Sua maioria se concentra na região sudeste e os docentes pesquisadores apresentam características bastante heterogêneas, relacionadas ao tempo de existência dos programas, à natureza da instituição ou filiação do docente.

Palavras Chave: Cientometria. Fisioterapia. Pesquisa.

\section{Introduction}

Contemporary societies are characterized by the dynamism and rapidity of the relations between production practices and scientific communication, as well as their dissemination and their potential for sociocultural representativeness [1]. These societies increasingly value the knowledge produced by the scientific method and renew domains to legitimize scientific culture [2]. The growth rate of scientific production in physiotherapy in the last decades has been accelerated [3]. Because of the natural urgency to treat health problems, the health area presents a high speed of production and dissemination of scientific knowledge [4].

The contribution to the progress of science and an evidence-based clinical practice is the main role of scientific publications on health, and in general, the production of this knowledge occurs in academic environments, especially in the stricto sensu graduate programs [5 - 7]. Particularly in the physiotherapy area, it is verified that the expansion of science has been expressed by the expansion of postgraduate programs, the number of Research National Council (CNPq in Portuguese) research groups, and the publications of scientific articles in indexed journals with a high-impact factor [8 - 12]. This growth is of paramount importance because it expands and improves the knowledge, standardize behaviors, and confirm or refute the experience of professional practice $[11,13]$.

A Brazilian physiotherapist researcher is extremely productive, from a scientific point of view, when compared with other health researchers $[3,10]$. Analyzing the profile of Brazilian physiotherapists, it is possible to observe a $900 \%$ increase in the number of doctorates of physiotherapists in Brazil in the last two decades, and this fact portrays the search for better qualification of these professionals and the development of the scientific bases of the profession, with positive effects on the labor market and attention to the population [10].

The hierarchy of the scientific community encourages those at lower levels to go up the scale of social recognition. However, because this movement threatens the status of those at the top, a spontaneous reaction occurs and is revealed in the scientometric indicators established by those in power. Because of this social capital, there are dominant and dominated scientists [14]. This movement provokes subversion strategies that considerably influence contemporary science [15].

Knowledge of the professional profile of Brazilian scientists in the physiotherapy area is important to understand the factors that influence the scientific 
behavior of this profession. Science needs to remain at the service of society and human development and, therefore, this work has the purpose of outlining the profile of Brazilian physiotherapist researchers, permanents, or collaborators professors of doctoral programs in the subarea of physiotherapy inserted in the 21 area of CAPES evaluation.

\section{Methods}

\section{Study Design and Population Sample}

The study of document analysis is conducted through the use of scientometric tools. The study population consisted of Brazilian physiotherapists with a PhD degree, who are characterized as permanent or collaborator professors of stricto sensu postgraduate programs in physiotherapy.

To identify the professionals, the Sucupira Platform database was used, in which the higher education institutions (HEI) that have a doctoral course inserted in the number 21 area of CAPES evaluation (physical education), specifically in physiotherapy and occupational therapy. Institutions authorized to offer doctoral courses were identified, and the websites of each institution were consulted to obtain the list of professors, permanent or collaborating, of doctoral course in physiotherapy.

After the professors' definition, the curriculum was found on the Lattes Platform, from CNPq individually, so that professors who, although working in graduate program in physiotherapy, graduated in another area were excluded. Publications from 2012 to 2016 were extracted from the curriculum of each researcher to identify the degree of authorship and collaboration among the researchers of the sample.

The nodes or intersections of the networks were differentiated with different colors to represent the researchers and the research areas, whereas the links of authorship and collaboration between researchers and the HEI can also be visualized through the connection. The size of the nodes or points of convergence and the thickness of the links between institutions and teachers are proportional to the number of articles in partnership in the different areas. The greater the number of articles published in partnership, the greater the thickness, and the greater the number of articles in a theme, the larger the size of the nodes.

\section{Variables analyzed in the Lattes Curriculum}

1) research area

2) higher education institution

3) guidelines completed at master's level

4) guidelines completed at the doctoral level

5) completed guidelines for scientific initiation

6) impact factor through Journal Citation Reports (JCR) from 2012 to 2016

7) full article numbers published in periodicals between 2012 and 2016

8) total mean of the impact factor through the JCR

9) CNPq research productivity grant

10) national publications

11) international publications

12) total number of publications

\section{Research areas categorized according to COFFITO (16)}

1) physiotherapy in acupuncture

2) cardiovascular physiotherapy

3) physiotherapy dermatofunctional

4) sports physiotherapy

5) physiotherapy in gerontology

6) neurofunctional physiotherapy

7) respiratory physiotherapy

8) physiotherapy in women's health

9) physiotherapy in occupational health

10) traumatic-orthopedic physiotherapy

\section{Study drawings by teachers categorized according to EQUATOR:}

1) randomized clinical trial

2) observational studies

3) systematic reviews

4) case study

5) qualitative research

6) diagnostic and prognostic studies

7) preclinical animal studies

8) study protocols

9) consensus and recommendations

10) quality of assistance

\section{Statistical Analyses}

Databases were established by the variables of each institution as well as of each researcher found. The data were tabulated and analyzed descriptively in percentage and absolute numbers for the categorical variables. Quantitative variables were analyzed by 
median and interquartile range. To test the associations between the selected variables, we used the Statistic Package for Social Science (SPSS) version 21 software, and for the statistical analyses, the ANOVA test with Bonferroni post hoc was applied to test the associations between categorical and quantitative variables, considering an alpha of 5\%. The GEPHI software in version 0.9 .1 was used to build the collaborative and association networks between institutions.

\section{Ethical aspects}

As previously mentioned, this study is constituted solely and exclusively of documentary analyses, with public data, of unrestricted access, discharacterizing the need for submission and approval of the Research Ethics Committees with human beings. No financial, legal, or political conflict by the authors or involving third parties, nor funding that could bring any type of conflict of interest has been determined. Names of the analyzed professors were hidden by coding in letters.

\section{Results}

Nine higher education institutions (HEI) were found with a $\mathrm{PhD}$ graduate program in physiotherapy in Brazil. As to the number of PhD members affiliated to these programs, a total of 119 permanent or collaborators professors with Lattes available were found, of which the majority is associated to UFMG (20.2\%), UFSCAR (17.6\%), UFRN (13.4\%), and UNINOVE (10.9\%). Regarding the type and study design developed in the research carried out by these professors, 71 (59.7\%) were observational studies, and 27 (22.7\%) were randomized clinical trials. Among these professors, only 40 (33.6\%) have CNPq research productivity grants (Table 1 ).

Table 1 - Characteristics of the researchers of the doctoral programs in physiotherapy, Brazil, March 2017

\begin{tabular}{lcc}
\hline & $\mathbf{N}=119$ & $\%$ \\
\hline Higher Educational Institutions & 7 & 5.9 \\
$\begin{array}{l}\text { Universidade Estadual de Londrina (UEL) } \\
\text { Universidade Federal de Ciências da Saúde de }\end{array}$ & 9 & 7.6 \\
$\begin{array}{l}\text { Porto Alegre (UFCSPA) } \\
\text { Universidade Federal de Minas Gerais (UFMG) }\end{array}$ & 24 & 20.2 \\
$\begin{array}{l}\text { Universidade Federal do Rio Grande do Norte } \\
\text { (UFRN) }\end{array}$ & 16 & 13.4 \\
\hline
\end{tabular}

(To be continued)
(Conclusion)

Table 1 - Characteristics of the researchers of the doctoral programs in physiotherapy, Brazil, March 2017

\begin{tabular}{|c|c|c|}
\hline & $\mathrm{N}=119$ & $\%$ \\
\hline Universidade Federal de São Carlos (UFSCAR) & 21 & 17.6 \\
\hline Universidade Estadual Paulista (UNESP) & 11 & 9.2 \\
\hline Universidade Cidade de São Paulo (UNICID) & 11 & 9.2 \\
\hline Universidade Nove de Julho (UNINOVE) & 13 & 10.9 \\
\hline Centro Universitário Augusto Motta (UNISUAM) & 7 & 5.9 \\
\hline \multicolumn{3}{|l|}{ Study design } \\
\hline Randomized clinical trial & 27 & 22.7 \\
\hline Observational study & 71 & 59.7 \\
\hline Preclinic studies with animal & 8 & 6.7 \\
\hline Qualitative research & 6 & 5.0 \\
\hline Systematic review & 7 & 5.9 \\
\hline \multicolumn{3}{|l|}{ Research area } \\
\hline Acupuncture & 1 & 0.8 \\
\hline Cardiovascular & 12 & 10.1 \\
\hline Dermatofunctional & 1 & 0.8 \\
\hline Sports & 13 & 10.9 \\
\hline Gerontology & 12 & 10.1 \\
\hline Neurofunctional & 25 & 21.0 \\
\hline Respiratory & 24 & 20.2 \\
\hline Women health & 5 & 4.2 \\
\hline Worker health & 6 & 5.0 \\
\hline Traumatic orthopedic & 20 & 16.8 \\
\hline \multicolumn{3}{|l|}{ Productivity research grant } \\
\hline Yes & 40 & 33.6 \\
\hline No & 79 & 66.4 \\
\hline
\end{tabular}

The median of the number of doctors graduated by the professors was 1.00 , whereas the guidelines finalized in scientific initiation were 12.00. The median of the total number of publications in international journals was 14.00 in international journals (Table 2).

Table 2 - Descriptions of quantitative variables selected on the profile of physiotherapists doctors working as teachers in Brazil, March 2017

\begin{tabular}{lccc}
\hline Variables & Q1 & Median & Q3 \\
\hline D0 & 0.00 & 1.00 & 6.00 \\
M0 & 5.00 & 10.00 & 17.00 \\
SI0 & 4.00 & 12.00 & 22.00 \\
Total of publications & 14.00 & 24.00 & 38.00 \\
IP & 7.00 & 14.00 & 24.00 \\
NP & 4.00 & 10.00 & 15.00 \\
Total mean of JCR & 0.79 & 1.19 & 1.81 \\
\hline & & \multicolumn{3}{c}{ (To be continued) }
\end{tabular}


Table 2 - Descriptions of quantitative variables selected on the profile of physiotherapists doctors working as teachers in Brazil, March 2017

\begin{tabular}{lccc}
\hline Variables & Q1 & Median & Q3 \\
\hline JCR 2012 & 0.37 & 0.95 & 1.73 \\
JCR 2013 & 0.40 & 1.00 & 1.72 \\
JCR 2014 & 0.32 & 1.17 & 1.62 \\
JCR 2015 & 0.42 & 1.07 & 1.93 \\
JCR 2016 & 0.54 & 1.20 & 1.85 \\
FPP 2012 & 3.00 & 5.00 & 9.00 \\
FPP 2013 & 2.00 & 5.00 & 9.00 \\
FPP 2014 & 2.00 & 5.00 & 9.00 \\
FPP 2015 & 3.00 & 5.00 & 8.00 \\
FPP 2016 & 2.00 & 3.00 & 7.00 \\
\hline
\end{tabular}

Note: $\mathrm{DO}=$ Doctoral Orientations; $\mathrm{MO}=$ Master Degree Orientations; SIO = Scientific Initiation Orientations; NP = National Publications; $\mathbb{I P}=$ International Publications; FPP = Full Papers Published; Q1 = Quartile 25\%; Q3 = Quartile 75\%. Source: Curriculum from Lattes Platform.

Preclinical study designs and randomized clinical trials were more common in doctoral guidelines, whereas systematic reviews had the highest JCR averages (Table 3).

Table 3 - Analysis of the association between study designs, number of completed guidelines, and publications of the permanent professors of doctoral programs in physiotherapy, Brazil, March 2017

\begin{tabular}{|c|c|c|c|c|c|c|}
\hline & 苞 & 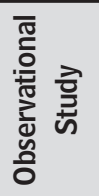 & 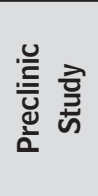 & 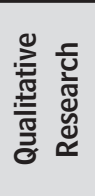 & 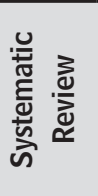 & 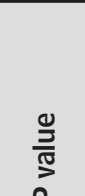 \\
\hline & 宽 & 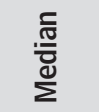 & 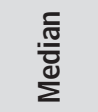 & 胥 & 胥 & \\
\hline DO & 13.00 & 9.00 & 18.50 & 3.50 & 9.50 & 0.089 \\
\hline MO & 3.00 & 1.00 & 4.50 & 1.50 & 2.00 & 0.134 \\
\hline SIO & 11.00 & 12.00 & 22.50 & 4.50 & 5.00 & 0.356 \\
\hline JCR 2012 & 1.22 & 0.85 & 2.66 & 0.31 & 1.62 & 0.000 \\
\hline JCR 2013 & 1.43 & 0.82 & 1.99 & 0.00 & 2.98 & 0.000 \\
\hline JCR 2014 & 1.39 & 1.03 & 1.19 & 0.45 & 2.21 & 0.046 \\
\hline
\end{tabular}

(To be continued)
(Conclusion)

Table 3 - Analysis of the association between study designs, number of completed guidelines, and publications of the permanent professors of doctoral programs in physiotherapy, Brazil, March 2017

\begin{tabular}{|c|c|c|c|c|c|c|}
\hline & 宽 & 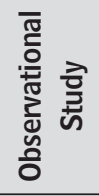 & 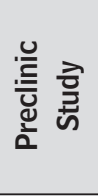 & 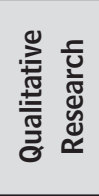 & 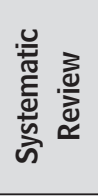 & $\frac{0}{\frac{0}{5}}$ \\
\hline & 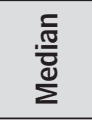 & 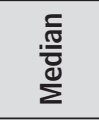 & 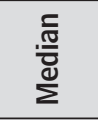 & 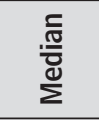 & 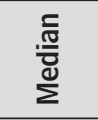 & \\
\hline JCR 2015 & 1.22 & 0.97 & 2.07 & 0.84 & 2.38 & 0.001 \\
\hline JCR 2016 & 1.58 & 0.90 & 1.80 & 1.02 & 2.37 & 0.007 \\
\hline Mean of JCR & 1.55 & 1.06 & 2.11 & 0.82 & 2.30 & 0.000 \\
\hline FPP 2012 & 7.00 & 4.00 & 6.00 & 4.50 & 6.00 & 0.754 \\
\hline FPP 2013 & 8.00 & 4.00 & 6.00 & 2.00 & 7.00 & 0.313 \\
\hline FPP 2014 & 5.00 & 5.00 & 5.50 & 2.00 & 7.00 & 0.537 \\
\hline FPP 2015 & 6.00 & 5.00 & 5.00 & 3.00 & 5.00 & 0.777 \\
\hline ACРP 2016 & 4.00 & 3.00 & 4.50 & 1.50 & 6.00 & 0.629 \\
\hline NP & 9.00 & 10.00 & 4.50 & 10.00 & 11.00 & 0.873 \\
\hline $\mathbb{P}$ & 21.00 & 12.00 & 13.50 & 4.00 & 24.00 & 0.67 \\
\hline
\end{tabular}

Note: $\mathrm{DO}=$ Doctoral Orientations; $\mathrm{M0}=$ Master Degree Orientations; SIO $=$ Scientific Initiation Orientations; NP $=$ National Publications; IP = International Publications; FPP = Full Papers Published; Q1 = Quartile 25\%; Q3 = Quartile 75\%. Source: Curriculum from Lattes Platform.

Despite having no significant difference between the institutions regarding the impact of scientific journals where they publish the results of their research, UFCSPA, UFRN, UFSCAR and UNICID presented the highest JCR averages. Institutions with the highest bibliometric indexes, in general, were UFRN with a JCR average of 1.73 and 7 international publications, UNICID with a JCR average of 1.67 and 31 international publications, UFCSPA with JCR Mean of 1.62 and 12 international publications, and UFSCAR with a JCR average of 1.64 and 18 international publications. On the other hand, the lowest scores were found in UEL with mean JCR of 0.59 and 9 international publications and in UNINOVE with JCR of 0.85 and 31 international publications (Table 4). 
Table 4 - Association between institutions, guidelines and publications of doctoral programs in physiotherapy, Brazil, March 2017

\begin{tabular}{lcccccccccc}
\hline & UEL & UFCSPA & UFMG & UFRN & UFCSAR & UNESP & UNICID & UNINOVE & UNISUAM \\
\cline { 2 - 9 } & Median & Median & Median & Median & Median & Median & Median & Median & Median & p ANOVA \\
\hline MO & 9.00 & 8.00 & 6.00 & 8.50 & 8.00 & 9.00 & 13.00 & 16.00 & 7.00 & 0.036 \\
D0 & 0.00 & 0.00 & 1.50 & 2.50 & 5.00 & 0.00 & 0.00 & 7.00 & 0.00 & 0.000 \\
SI0 & 14.00 & 4.00 & 7.00 & 4.00 & 20.00 & 11.00 & 10.00 & 27.00 & 8.00 & 0.004 \\
JCR 2012 & 0.06 & 2.07 & 1.07 & 0.69 & 1.22 & 0.72 & 1.73 & 0.60 & 0.85 & 0.076 \\
JCR 2013 & 0.26 & 0.68 & 0.90 & 0.65 & 1.31 & 0.59 & 1.46 & 0.90 & 1.00 & 0.403 \\
JCR 2014 & 0.38 & 1.37 & 1.22 & 0.00 & 1.49 & 0.50 & 1.50 & 1.03 & 0.70 & 0.130 \\
JCR 2015 & 0.42 & 1.79 & 0.39 & 1.50 & 1.66 & 0.94 & 1.64 & 1.08 & 0.99 & 0.092 \\
JCR 2016 & 0.98 & 1.28 & 1.01 & 0.12 & 1.45 & 1.24 & 1.73 & 1.17 & 0.89 & 0.404 \\
Mean JCR & 0.59 & 1.62 & 1.18 & 1.73 & 1.64 & 1.03 & 1.67 & 0.85 & 1.01 & 0.359 \\
FPP 2012 & 4.00 & 3.00 & 4.00 & 4.00 & 4.00 & 6.00 & 6.00 & 8.00 & 3.00 & 0.126 \\
FPP 2013 & 4.00 & 3.00 & 4.00 & 2.00 & 6.00 & 6.00 & 5.00 & 9.00 & 6.00 & 0.003 \\
FPP 2014 & 7.00 & 4.00 & 3.00 & 2.00 & 6.00 & 7.00 & 5.00 & 10.00 & 6.00 & 0.004 \\
FPP 2015 & 6.00 & 4.00 & 3.00 & 3.50 & 3.00 & 8.00 & 5.00 & 8.00 & 6.00 & 0.011 \\
FPP 2016 & 3.00 & 3.00 & 2.00 & 1.50 & 3.00 & 6.00 & 3.00 & 5.00 & 4.00 & 0.001 \\
NP & 17.00 & 7.00 & 5.50 & 9.00 & 7.00 & 13.00 & 9.00 & 13.00 & 10.00 & 0.039 \\
IP & 9.00 & 12.00 & 10.50 & 7.00 & 18.00 & 31.00 & 14.00 & 31.00 & 18.00 & 0.003 \\
\hline
\end{tabular}

Among the areas of physiotherapy studied by professors, the highest frequency was found in the area of neurofunctional (20.7\%), followed by respiratory $(19.8 \%)$, and traumatology and orthopedics (16.5\%). The lowest frequencies were the studies of acupuncture $(0.8 \%)$ and dermatofunctional $(0.8 \%)$. Strong collaborations are observed among UFMG, UNINOVE, and UFSCAR professors. Greater isolation is observed in UNISUAM and UEL (Figure 1).

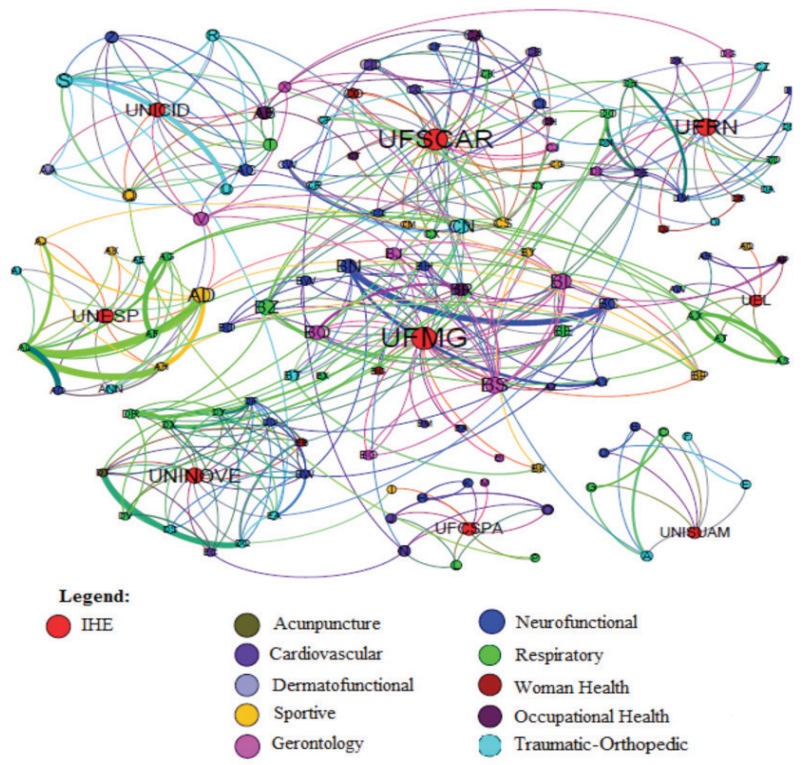

Figure $\mathbf{l}$ - Collaboration network among physiotherapists teachers of stricto sensu postgraduation programs in physiotherapy in Brazil between the years of 2012 and 2016.

\section{Discussion}

The profile of a physiotherapist researcher in Brazil is of great importance to the scientific community to be able to configure and expose possible gaps in knowledge or even to set goals to be followed to improve the current cadres, tools, and scientific evidence used for the interventions of the professional physiotherapy and the knowledge about this professional $[16,17]$. Several tools allow the evaluation of the different aspects related to scientific phenomena, and through scientometric techniques, it was possible to delineate the profile of physiotherapist researchers who occupy the top level of doctoral programs throughout Brazil [18].

In Brazil, a large part of research, experiments, and scientific advances are induced and financed by sectoral policies that are carried out mainly by two important Brazilian agencies: the Coordination of Improvement of Higher Education Personnel (CAPES in Portuguese) and the National Council for Scientific Development and Technological (CNPq in Portuguese), they are responsible for promoting events, such as congresses, in the most diverse areas of health and funding studies with scholarships for masters, doctorates, and so on [19]. Criteria adapted in the evaluation of proposals, researchers, research projects, and requests for funding these agencies are established by those who hold the highest positions 
in the Brazilian academic hierarchy [20]. It is public knowledge that these criteria are comparative and deeply affected by complex phenomena, often unconscious and not properly proven [2].

Of course, stricto sensu graduate courses, such as master's and doctoral degrees, which have a longer implementation time, that is, the older ones, are on a plateau ahead and occupy the top of the rankings for financing, the publications, so as to remain constantly in these positions [3]. Professors affiliated to these more traditional and wellknown programs, academically and scientifically, generally evaluate and set up their own evaluation criteria, which can, of course, generate conflicts of interest [14]. The higher concentration of new doctors in the southeast seems to be contrary to the goals of the current National Post-Graduation Plan (PNPG in Portuguese), which should reduce regional asymmetry $[4,12]$. Clearly, observing the distinctive health and research conditions in the north, northeast, and midwest regions, the development of science in physiotherapy, because it depends on the approval of new courses, is often difficult and without future perspectives $[11,12]$. This phenomenon limits the studies on disadvantaged populations that have endemic conditions in those regions [9]. For this reason, evaluations of projects, funding, events, and institutions should be adjusted to specific regional conditions to promote the advancement of research in physical therapy in other parts of the country.

Considering that the capacity to train new human resources for research is one of the ways to feed the scientific production chain of knowledge [2,20], there are scientific initiation programs and postgraduate courses at the masteral and doctorate degrees, where capturing of students often expresses the capacity of orientation of the permanent professors because they represent how attractive and recognized they are in the academic and scientific world to carry out these attributions [14]. When compared with other areas of knowledge, it is observed that there are still insufficient capacities developed in this regard in the permanent professors of physiotherapy [4].

The difference and distance between the profile and curriculum of CNPq research productivity fellows and professors belonging to the everlasting team of older graduate programs are noticeable $[3,21]$. The total amount of publications, and even the quality, expresses the productive capacity of these professors. An important fact to note is that the total number of articles published is at least double the number of masters and doctoral degrees accomplished. This phenomenon probably says that the number of publications resulting from the researches developed in the programs is of two articles by each orienting in average. It may also be that professors publish articles also in collaboration with other professors, or with their superiors, for example, in a postdoctoral course, which means publications without their respective students [7].

The findings about the quality of publications in physiotherapy, despite the fact that this is far from an ideal reality, suggest that the Brazilian physiotherapist is very productive. Our findings, however, show that private institutions have indicators comparable with those of public institutions with a long time of existence. Taking into account the investment in research and development, regardless of its model or purpose, if it is important, it may be that private institutions have resources destined exclusively for the cost of publications, which causes them to reach higher and better indexes, and that there is still no simple and objective measure that can faithfully represent the quality of the researches produced [22 - 24]. However, when one observes the impact of the journals of the publications carried out, professors from an institution in the southern region with little time of existence satisfactorily fulfill this indicator when compared with the southeast region [10].

It is worth noting that in the observation of dispersion measures, even institutions with traditional and old programs have teachers with very heterogeneous characteristics. It is probable that considerations about the notorious knowledge of older researchers limit their exclusion from permanent bodies, even though they cannot produce scientifically to fill the metrics indexes proposed by CAPES [14]. High confidence interval in several variables expresses the heterogeneity of Brazilian postgraduation stricto sensu in the physiotherapy area.

It is important to note that published articles, regardless of their origin, bring individual benefits to the authors to maintain their accreditation with the postgraduate programs [14]. Pressure for publications in high-impact journals generates competitiveness and strategies, consciously or unconsciously, to ensure better positions in academic settings, which distorts the reality of publications [18]. The impact factor cannot express the real quality of the researches but the visibility of the journals [25], making it necessary to have more precise criteria for the selection of the financings, as well as the 
evaluation of the quality of the researches carried out all over Brazil, to observe what the real impact is on the results and what the benefits to society are.

Among the areas of knowledge of the researchers analyzed, the neurofunctional area is the one that receives the most attention and dedication in research by the physiotherapists, followed by the areas of respiratory and gerontology. This fact had already seen observed since 2009 [17]. Perhaps, chronic and degenerative conditions, with sequelae and dementia, require more urgent research that contributes to the development of the functional independence of communities and can reduce the indirect costs to society [26]. The reasons for the knowledge in osteopathy receive less attention, it may be related to the fact that it is a discipline and area not directly addressed in undergraduate courses, being only regulated as a specialty of the physiotherapist in 2001 [16], which may suggest a lack of interest in research in this field [27]. Strategies of dissemination in networks of researchers have been emphasized as a possibility to increase the visibility of scientific production and quotations [28].

It was noted that preclinical trials and randomized clinical trials are the most performed by teachers, especially in doctoral projects. It is understandable that this factor is related to the average time indicated by CAPES to obtain the titration [21], which can guarantee the student a time of intervention and analysis of the data. On the other hand, the systematic reviews were the ones that presented the highest impact factor averages, perhaps related to the valorization of clinical practice based on the best evidence, and encouraging researchers to invest efforts in this type of study [5]. In general, it is necessary that scientific information is always gathered, organized, critically evaluated, as in compendia and quantitatively measured, which may account for this relevance of systematic reviews for research in physiotherapy [21].

It was possible to confirm that the observational studies were the principal surveys with original data. It is often possible to believe that the choice of study is influenced by the feasibility and time available for its completion [12]. The choice of study design has to be the one that best applies to the subject and objectives of the studies or to the diseases to be studied, and the success of a scientific research depends fundamentally on the maturity and experience of the researchers who usually seek studies that bring information that are relevant to the field $[13,29]$.
Evaluating and critically exposing academic and scientific production is a very complex task [23], and among the forms of CNPq funding, the Research Productivity Grant (PQ) stands out, which is attributed to the researchers from all areas, based not only on the quality of a submitted project but also, mainly, on the quality of the researcher $[3,10,18]$. Of the 119 teachers analyzed, one third are benefited by this modality of funding, which often boosts the growth of research quality, attraction for orientation by that teacher, as well as the qualification of the graduate program to which that researcher is affiliated [30].

The possibility of evaluation through the Sucupira and Lattes platforms, the postgraduate programs in physiotherapy, as well as the professors researchers, were the aspects to be exalted in this study, besides the facility for data collection and analysis with low costs. The lack of analysis of the articles that would allow a more careful evaluation of the existence of publications including the students was a limitation, as well as the lack of more precise indicators on the quality of the research, which leads us to the limitations of assigning to the JCR which do not really represent the impact of research in the field [25].

The analysis of the findings shows that there is still a minor investment in physiotherapy research in Brazil, with a poor distribution in relation to the regions and that more complex phenomena can influence the behavior of the researchers [4]. Many scientometric studies must be developed to contribute to the development of the profession and to provide subsidies for political action by the public and private sectors [30].

\section{Conclusion}

It is possible to infer that there are few programs for the specific doctorate of physiotherapists in Brazil. These are concentrated in the southeast region, and the professors have heterogeneous characteristics in many of the indicators analyzed. The nature of the institution and the duration of the programs do not ensure the quality of researchers and publications by the current metrics. Funding agencies need to invest in expanding funding for research in physiotherapy, with scholarships and equipment, support for different journals in the area, and subsidy for publications in vehicles with free access and greater impact. 


\section{References}

1. Chiarini T, Vieira KP. Universidades como produtoras de conhecimento para o desenvolvimento econômico: sistema superior de ensino e as políticas de CT\&I. Rev Bras Econ. 2012;66(1):117-32.

2. Bufrem LS, Silva FM, Sobral NV. Análise das influências intelectuais na produção científica da área de Ciência da Informação: um estudo sobre os bolsistas de produtividade em pesquisa (PQ-CNPq). In: Edição Especial 5 EBBC. Em Quest. 2017;23(Spec No):115-41.

3. Sturmer G, Viero CCM, Silveira MN, Lukrafka JL, Plentz RDM. Profile and scientific output analysis of physical therapy researchers with research productivity fellowship from the Brazilian National 17 Council for Scientific and Technological Development. Br J Phys Ther. 2013;17(1):41-8.

4. Rezende, SR. Produção científica e tecnológica no Brasil: conquistas recentes e desafios para a próxima década. Rev Adm Empres. 2011;51(2):202-9.

5. Marques AP, Peccin MS. Pesquisa em fisioterapia: a prática baseada em evidências e modelos de estudos. Fisioter Pesqui. 2005;11(1):43-8.

6. Shariat A, Tamrin SBM, Arumugam M, Danaee M, Ramasamy R. The need for evidence-based exercise prescription for office workers. Malaysian Journal of Publica Health Medicine 2016;16(3):52-5.

7. Evans C, Stevenson K. The experience of international nursing students studying for a $\mathrm{PhD}$ in the U.K: A qualitative study. BMC Nurs. 2011;10:11.

8. Dennis S, Watts I, Pan Y, Britt H. Who do Australian general practitioners refer to physiotherapy? Aust Fam Physician. 2017;46(6):421-6.

9. Agho AO, Jonh EB. Occupational therapy and physiotherapy education and workforce in Anglophone sub-Saharan Africa. Hum Resour Health. 2017;15(1):37.

10. Freire RS, Oliveira EA, Silveira MF, Martelli DRB, Oliveira MCL, Martelli Jr H. Perfil dos pesquisadores na área de Fisioterapia e Terapia Ocupacional no Conselho Nacional de Desenvolvimento Científico e Tecnológico. RBPG. 2013;10(19):11-24.

11. Warken GLRB, Freitas JJS, Domingues RJS, Kietzer KS. A formação acadêmica e a produção do conhecimento científico do fisioterapeuta pesquisador amazônida. RBPG. 2015;12(29):743-68.
12. Cruz FG, Cohim S, Carneiro APQ, Sá KN. Perfil do fisioterapeuta pesquisador docente no estado da Bahia: uma análise documental. Rev Pesqui Fisioter. 2017;7(1):70-8.

13. Droescher FD, Silva EL. O pesquisador e a produção científica. Perspect Cienc Inf. 2014;19(1):170-89.

14. Maricato JM, Alves IM, Martins DL. Análise multivariada de componentes principais dos fatores que interferem no (não) credenciamento de pesquisadores em programas de pós-graduação. R Ibero-amer Ci Inf. 2016;9(1):108-23.

15. Mueller SPM. A comunicação cientifica e o movimento de acesso livre ao conhecimento. Ci Inf. 2006;35(2):27-38.

16. CREFITO 2 - Conselho Regional de Fisioterapia e Terapia Ocupacional da $2^{\mathrm{a}}$ Região. Resoluções Coffito. 2001 [cited 2017 Apr 14]. Available from: https:// tinyurl.com/yblbrnrf.

17. Coury HJCG, Vilella I. Perfil do pesquisador fisioterapeuta brasileiro. Rev Bras Fisioter. 2009;13(4):356-63.

18. Wainer J, Vieira P. Avaliação de bolsas de produtividade em pesquisa do CNPq e medidas bibliométricas: correlações para todas as grandes áreas. Perspect Cienc Inf. 2013;18(2):60-78.

19. Silva Jr JR, Kato FBG. A Política de Internacionalização da Educação Superior no Plano Nacional de PósGraduação (2011-2020). Rev Inter Educ Sup. 2016:2(1):138-51.

20. Domingues AA. A coordenação estratégica das políticas internacionais de ciência e tecnologia. Cad Pesq Interdisc Ci-s Hum-s. 2014;15(107): 180-96.

21. Padula RS, Pires RS, Alouche SR, Chiavegato LD, Lopes AD, Costa LOP. Análise da apresentação textual de revisões sistemáticas em fisioterapia publicadas no idioma português. Rev Bras Fisioter. 2012;16(4):281-8.

22. Kolahdoozan S, Massarrat S. Progress of Iran in Medical Research. Acta Med Iran. 2016;54(11): 690-5.

23. Massarrat S, Kolahdoozan S. Critical assessment of progress of medical sciences in Iran and Turkey: the way developing countries with limited resources should make effective contributions to the production of science. Arch Iran Med. 2011;14(6):370-7. 
24. Richter RR, Schlomer SL, Krieger MM, Siler WL. Journal publication productivity in academic physical therapy programs in the United States and Puerto Rico from 1998 to 2002. Phys Ther. 2008;88(3):376-86.

25. Hirsch JE. An index to quantify an individual's scientific research output. Proc Natl Acad Sci U S A. 2005;102(46):16569-72.

26. Talmelli LFS, Vale FAC, Gratão ACM, Kusumota L, Rodrigues RAP. Doença de Alzheimer: declínio funcional e estágio da demência. Acta Paul Enferm. 2013;26(3):219-25.

27. Guimarães BM, Martins LB, Barkokébas Jr B. Issues concerning scientific production of including people with disabilities at work. Work. 2012;41(Suppl 1):4722-8.
28. Memon AR. ResearchGate is no longer reliable: leniency towards ghost journals may decrease its impact on the scientific community. J Pak Med Assoc. 2016:66(12):1643-7.

29. Guimarães JA. A pesquisa médica e biomédica no Brasil. Comparações com o desempenho científico brasileiro e mundial. Cienc Saude Coletiva. 2004;9(2):303-27.

30. Cavalcante CCL, Rodrigues ARS, Dadalto TV, Silva EB. Evolução científica da fisioterapia em 40 anos de profissão. Fisioter Mov. 2011:24(3):513-22.

Received in $10 / 23 / 2017$

Recebido em 23/10/2017

Approved in 11/06/2017

Aprovado em 06/11/2017 